\title{
Effect of decomposition temperature on crystallite size and strain for
} alumina

https://doi.org/10.32792/utq/utj/vol10/1/6

\author{
Sattar A.Abass \\ Science department, college of \\ Basic education, Waist University \\ sattarabass@yahoo.com
}

\author{
Ghazi K.Saeed \\ Science department, college of \\ Basic education, Waist University \\ phyghazi@ymail.com
}

\begin{abstract}
The crystallite size and strain of $\mathrm{Al}_{2} \mathrm{O}_{3}$ ceramic powder have been determined from $\mathrm{x}$-ray line-broadening analysis at different decomposition temperatures. The $\mathrm{Al}_{2} \mathrm{O}_{3}$ powder have been prepared from decomposition of aluminum hydroxide $\mathrm{Al}(\mathrm{OH})_{3}$ at different temperature which have been characterized by X-Ray diffraction (XRD) and Differential, Thermal Analysis (DTA) methods. Deconvolution of the experimental profiles by Fourier cosine coefficients has resulted in corrected values of crystallite size. The crystallite size has been found to increase with increasing decomposition temperature from $38 \mathrm{~nm}$ at $1673 \mathrm{k}$ to $73 \mathrm{~nm}$ at $1873 \mathrm{k}$. Strain on the other hand decrease from $3.04 \times 10^{-3}$ at $1673 \mathrm{k}$ to $1.14 \times 10^{-3}$ at $1873 \mathrm{k}$. Estimation of micro hardness on compacts of different crystallite size has shown that crystallite size may influence the bearing load that compact can endure.
\end{abstract}

Keywords: crystallite size, strain, different decomposition temperatures, thermal analysis

\section{1- Introduction :-}

Aluminum minerals have been used extensively in the construction of open-hearth furnace for steel industry and in the production of rubber; plastics fine chemicals, paper pulp, protective surface on the metal, boards, and in water treatment.

Aluminum oxide is usually produced by calcining $\mathrm{Al}(\mathrm{OH})_{3}$ above $673 \mathrm{k}$. The reactivity of the produced $\mathrm{Al}_{2} \mathrm{O}_{3}$ depended on the calcinations temperature, and above $1673 \mathrm{k}$ it is in the unreactive from which is used as basic refractory bricks ${ }^{[1-6]}$.

Determination of the crystallite size and morphology of $\mathrm{Al}_{2} \mathrm{O}_{3}$ prepared by calcinations of aluminum hydroxide, made by use of x-ray diffraction method and electron microscopy have shown that crystallite size extend over a range of values from 50 to $1000^{\circ} \mathrm{A}$ and the morphology of the decomposed product is similar to that of the parent compound ${ }^{[7]}$. The present investigation aimed to calculate crystallite size, strain 


\section{University of Thi-Qar Journal Vol.10 No.1 Mar 2015}

Web Site: https://jutq.utq.edu.iq/index.php/main Email: journal@jutq.utq.edu.iq

and morphology from decomposed aluminum hydroxide and to show if these have any influence on the hardness properties.

\section{2-Experimental:}

To characterize the reactants and their decomposition, different techniques were used. They were the automated x-ray powder diffraction system for recording diffraction pattern with copper $\mathrm{K}_{\boldsymbol{\alpha}}$ radiation $\left(\lambda=1.5406 A^{\circ}\right)$. In addition to the necessary treatment on the scanned peaks, the simultaneous TG-DTA system for recording TG and DTA curves under static air, heating rate of $10^{\circ} \mathrm{C} / \mathrm{min}$ and alumina as reference material .

Assessment of mechanical properties of powder compacts by Vickers micro hardness was made with applied load of 100 gram and square diamond pyramid with opposite faces at $136^{\circ}$.

\section{3-Analysis of Line Breath}

The extent of line breadth was taken as a measure due to small-crystallite of $\mathrm{Al}_{2} \mathrm{O}_{3}$ powders. Measurements were based on the FWHM (Full Width at Half Maximum) of three diffraction lines namely (104), (113) and (116). The measured breadths were corrected for instrumental effects using the breadth from normal crystallite size specimen by using the equation given by Azarof ${ }^{[8]}$.

$$
B_{\mathrm{WC}}=\left[\left(\mathrm{B}_{\text {meas. }}-\mathrm{B}_{\text {instr. }}\right)\left(\mathrm{B}_{\text {meas. }}^{2}-\mathrm{B}_{\text {instr. }}^{2}\right)^{1 / 2}\right]^{1 / 2}
$$

Where $B_{\text {meas. }}$ is the experimentally measured breadth and $B_{\text {instr. }}$ is the half width of the instrumental breadth.

The crystallite size and strain can be calculated from formula ${ }^{[9]}$, when certain line shape is assumed such as Gaussian or Cauchy functions.

$$
L_{W C}=\frac{K \lambda}{B_{W C} \operatorname{Cos} \theta}
$$

$\epsilon=\frac{B_{W C}}{4 \tan \theta}$

Where $L_{W C}$ is the crystallite size, $\lambda$ is the wavelength of the radiation, $B_{W C}$ is the corrected breadth (in radians), $\boldsymbol{\theta}$ is the Bragg angle, $\mathrm{K}$ is the Scherer constant whose value $2(\operatorname{In} 2 / \pi)^{1 / 2}=0.94^{[10]}$, and $\epsilon$ is the strain.

In practice the line shape is not truly Gaussian or Cauchy and in order to proceed with the correction for instrument function, deconvolution of the experimental profiles was performed by the method proposed by Stokes $(1948)^{[11]}$, and Warren (1969) ${ }^{[10]}$ and the Fourier cosine coefficients $A_{L}$ were plotted against $L$ where $L$ is defined as ${ }^{[12]}$. 


\section{University of Thi-Qar Journal Vol.10 No.1 Mar 2015}

Web Site: https://jutq.utq.edu.iq/index.php/main Email: journal@jutq.utq.edu.iq

$L=\frac{n \lambda}{2\left(\sin \theta_{2}-\sin \theta_{1}\right)}$

Where $\theta_{2}$ and $\theta_{1}$ are the limits over which the line is recorded, and $n$ is the Fourier harmonic number. Calculation of $A_{L}$ was made with the aid of computer program written specifically for this purpose.

The corrected cosine coefficient $A_{L}$ can be written as:

$$
A_{L}=A_{L}^{S} A_{L}^{D}
$$

Where $A_{L}^{S}$ is the size coefficient and $A_{L}^{D}$ is the distortion. So the crystallite size $\mathrm{L}_{\mathrm{f}}$ in direction perpendicular to the diffracting planes considered can be obtained from the initial slope of the curve of $A_{L}^{S}$ versus $\mathrm{L}$ or $\mathrm{A}_{\mathrm{L}}$ versus $\mathrm{L}$, if we neglect the distortion coefficient.

$$
\frac{1}{\mathrm{~L}_{\mathrm{f}}}=\left|\frac{\mathrm{dA} \mathrm{L}}{\mathrm{dL}}\right|_{\mathrm{L}-0}
$$

Since the distribution is Gaussian, strain also contributes to the broadening of the profile. As multiple orders are not available, r.m.s. strains were calculated following Mitra and Misra (1967) ${ }^{[13]}$ where:

$\mathrm{A}_{\mathrm{L}}=\exp \left(-2 \pi^{2} \mathrm{I}^{2} \mathrm{~L}_{\mathrm{L}}^{2}\right) \quad$ and

$\mathrm{Z}_{\mathrm{L}}=\frac{L \in}{d}$

Where $\epsilon=$ r.m.s. strain, and $\mathrm{I}=$ order of reflection.

\section{4-Results and Discussion:}

Figure (1) shows the DTA, TG, and DDTA curves as recorded for $\mathrm{Al}(\mathrm{OH})_{3}$.Figure (2) shows the $\mathrm{X}$-Ray diffraction patterns of $\mathrm{Al}(\mathrm{OH})_{3}$ at $1673 \mathrm{~K}, 1773 \mathrm{~K}$ and $1873 \mathrm{~K}$. Figure (3) shows the variation of the FWHM with decomposition temperature for $\mathrm{Al}_{2} \mathrm{O}_{3}$ from aluminum hydroxide. For the three reflections (104), (113) and (116) the half width decreases sharply up to $1800^{\circ} \mathrm{C}$ and slowly up to $1870^{\circ} \mathrm{C}$. The variation of FWHM with decomposition time of $\boldsymbol{\alpha}-\mathrm{Al}_{2} \mathrm{O}_{3}$ shows in Figures (4). Figure (5) shows the plot of the Fourier cosine coefficient $A_{L}$ with $L$ for different temperatures, for alumina from aluminum hydroxide. The (104) reflection has been taken as a representative example only. The crystallite sizes at different temperatures were determined from the initial slopes of the curves. The results are shown in table (1) with crystallite size for (104), (113), and (116) reflection as well. The different sizes with respect to different reflections indicate the anisotropic nature of the crystallites in these directions.

Temperature has significant effect on the crystallite sizes and strain of $\mathrm{Al}_{2} \mathrm{O}_{3}$ irrespective of the starting materials. As the temperature increases, the size of the 


\section{University of Thi-Qar Journal Vol.10 No.1 Mar 2015}

Web Site: https://jutq.utq.edu.iq/index.php/main Email: journal@jutq.utq.edu.iq

crystallites perpendicular to (104), (113), and (116) reflections increases steadily. The inverse behavior is observed for strain. The crystallite sizes and strain values obtained in this work are in agreement with those for $\mathrm{Al}_{2} \mathrm{O}_{3}, \mathrm{MgO}, \mathrm{ZnO}, \mathrm{MnO} 2$ found in the literature $^{[14-17]}$.

In table (1) we have presented values of crystallite size and strain obtained from Fourier method for the purpose of comparison.

Table (2) observed that Vickers micro hardness number of $\mathrm{Al}_{2} \mathrm{O}_{3}$ powder compacts depend on the crystallite size determined at certain temperature with the lower crystallite size of $40 \mathrm{~A}^{\circ}$ having higher hardness number of 884 and higher size of $70 \mathrm{~A}^{\circ}$ having hardness number of 731 . This means that compacts made from finer powders endure better loads.

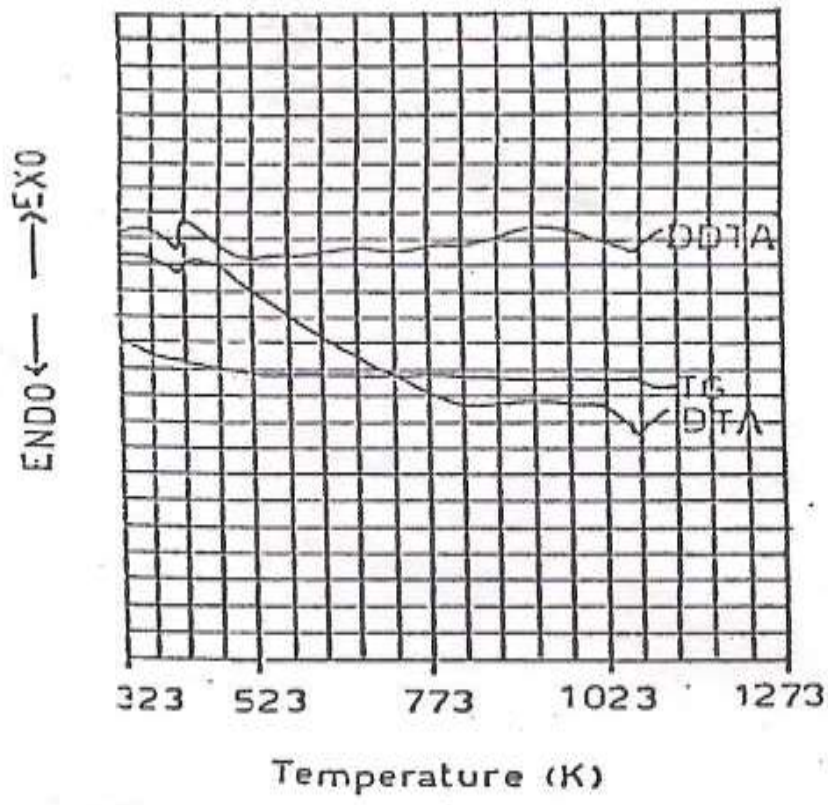

Figure (1) DTA, TG, and DDTA curves as recorded for $\mathrm{Al}(\mathrm{OH})_{3}$, heating rate $10 \mathrm{~K} / \mathrm{min}$.

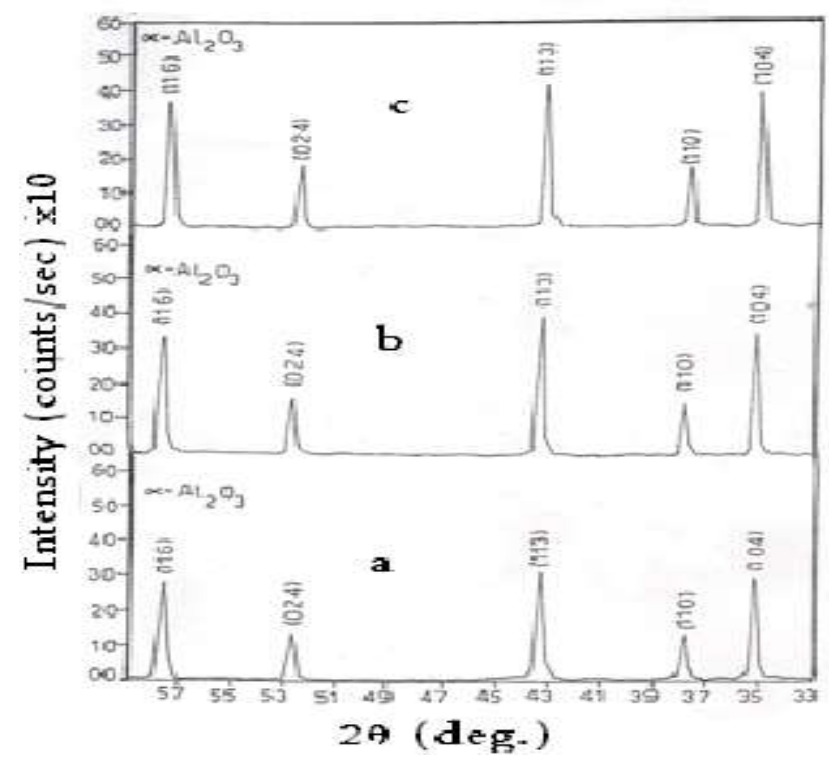


Web Site: https://jutq.utq.edu.iq/index.php/main Email: journal@jutq.utq.edu.iq

Figure (2) X-Ray diffraction patterns of $\mathrm{Al}(\mathrm{OH})_{3}$ at $1673 \mathrm{~K}, 1773 \mathrm{~K}$, and $1873 \mathrm{~K}(\mathrm{a}, \mathrm{b}$ and $\mathrm{c}$ respectively)

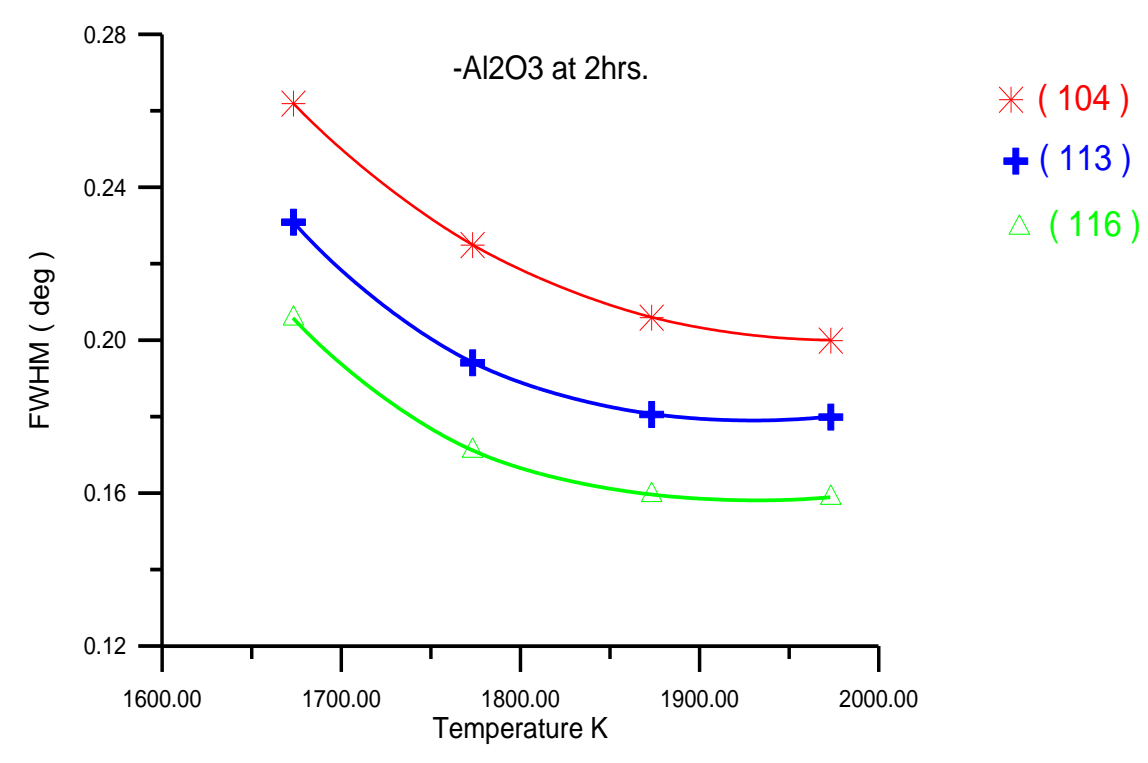

Figure (3) Variation of FWHM with decomposition temperature of $\boldsymbol{\alpha}-\mathrm{Al}_{2} \mathrm{O}_{3}$.

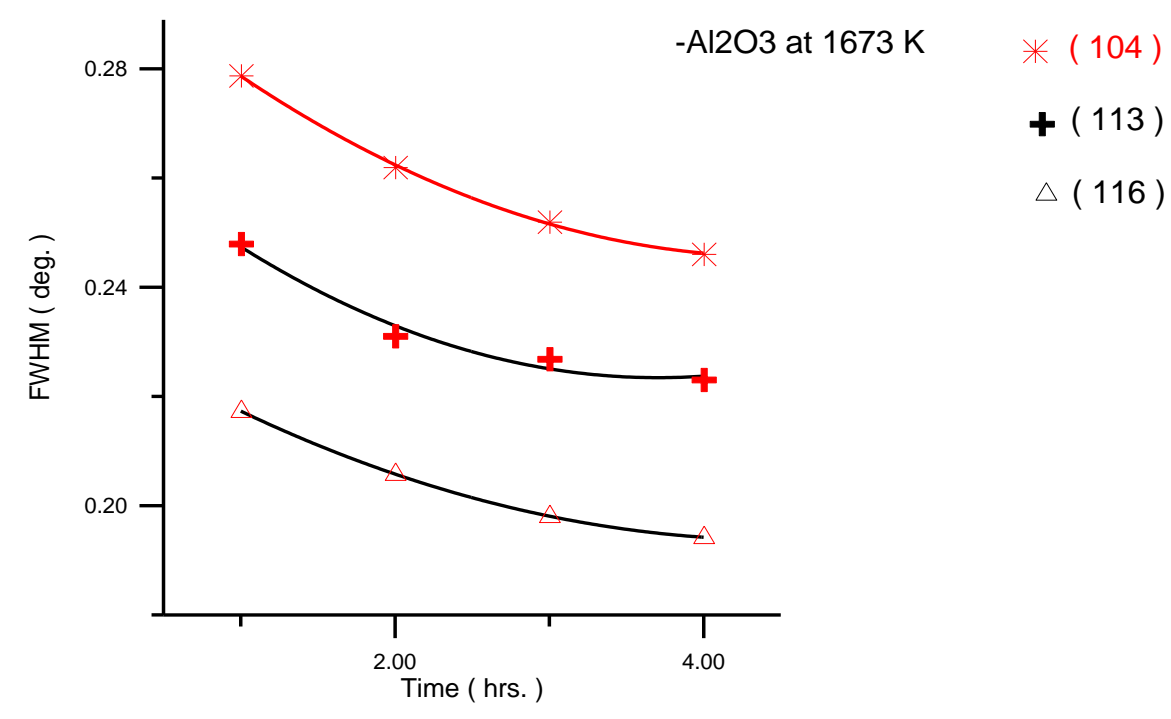




\section{University of Thi-Qar Journal Vol.10 No.1 Mar 2015}

Web Site: https://jutq.utq.edu.iq/index.php/main Email: journal@jutq.utq.edu.iq

Figure (4) Variation of FWHM with decomposition time of $\boldsymbol{\alpha}-\mathrm{Al}_{2} \mathrm{O}_{3}$.

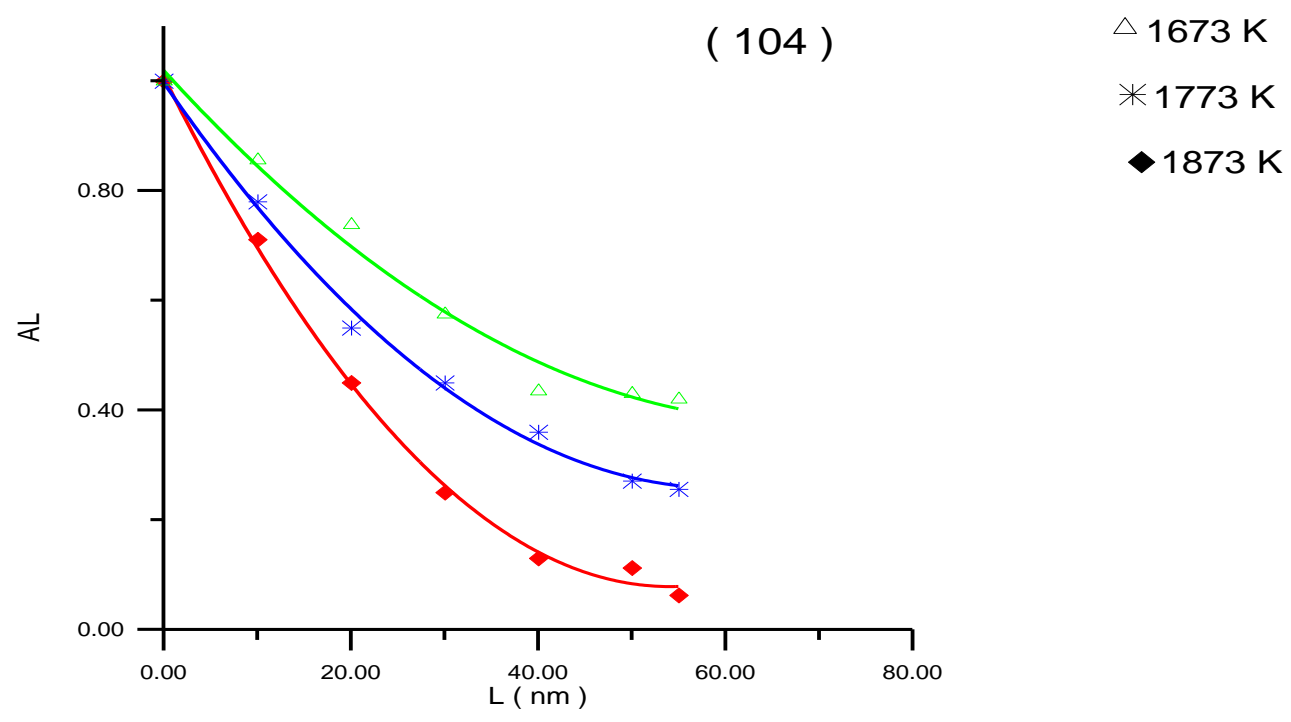

Figure (5) plot of $\mathrm{A}_{\mathrm{L}}$ against $\mathrm{L}$ in $\boldsymbol{\alpha}-\mathrm{Al}_{2} \mathrm{O}_{3}$ obtained at $1673 \mathrm{~K}, 1773 \mathrm{~K}$ and $1873 \mathrm{~K}$ for 104 reflection .

Table (1) Crystallite size and r.m.s. strain as calculated by Fourier analysis for $\boldsymbol{\alpha}-\mathrm{Al}_{2} \mathrm{O}_{3}$ yielded from thermal decomposition of $\mathrm{Al}(\mathrm{OH})_{3}$.

\begin{tabular}{|c|c|c|c|}
\hline $\begin{array}{c}\text { Reflection } \\
\mathrm{hkl}\end{array}$ & $\begin{array}{c}\text { Temperature } \\
(\mathrm{K})\end{array}$ & $\begin{array}{c}\text { Crystallite size } \\
(\mathrm{nm})\end{array}$ & $\begin{array}{c}\text { r.m.s. } \\
\text { strain } \times 10^{-3}\end{array}$ \\
\hline 104 & 1673 & 38 & 3.04 \\
& 1773 & 52 & 2.66 \\
& 1873 & 68 & 2.55 \\
\hline 113 & 1673 & 43 & 2.60 \\
& 1773 & 60 & 2.30 \\
& 1873 & 72 & 2.16 \\
\hline 116 & 1673 & 47 & 1.58 \\
& 1773 & 63 & 1.25 \\
& 1873 & 73 & 1.14 \\
\hline
\end{tabular}

Table (2) Vickers hardness number of $\boldsymbol{\alpha}-\mathrm{Al}_{2} \mathrm{O}_{3}$ derived from $\mathrm{Al}(\mathrm{OH})_{3}$ at $1673 \mathrm{~K}, 1773 \mathrm{~K}$ and $1873 \mathrm{~K}$. 


\section{University of Thi-Qar Journal Vol.10 No.1 Mar 2015}

Web Site: https://jutq.utq.edu.iq/index.php/main Email: journal@jutq.utq.edu.iq

\begin{tabular}{|c|c|c|c|c|}
\hline $\begin{array}{c}\text { Temperature } \\
(\mathrm{K})\end{array}$ & $\mathrm{Y}(\boldsymbol{\mu \mathrm { m }})$ & VHN & $\begin{array}{c}\text { Crystallite Size } \\
(\mathrm{nm})\end{array}$ & Mean VHN \\
\hline 1673 & 14 & 946 & 40 & 884 \\
& 15 & 824 & & \\
\hline 1773 & 14.5 & 882 & & 779 \\
& 16 & 742 & 50 & \\
& 15.5 & 824 & & 731 \\
\hline 1873 & 16.5 & 680 & 70 & \\
& 15.5 & 771 & & \\
& 16 & 742 & & \\
\hline
\end{tabular}

\section{References}

[1] T.P. Whaley,(1981),"Speciality lnorganic chemicals", ed by R.Thomson, pp. 122163.

[2] W.E.Worral L2m Constrnction chemicals , Inc. Grib it and Grib it AO, non. Slie aluminium oxide floor treatment (1998).

[3] D.J. Driscoll, et al., (1985), J. AM Chem. Soc., 107, 58 .

[4] P. Maass, M. Meyer, A. Bunde "physics A 266(1999) 197-202.

[5] Paul pajunen, P. Eng . "Eco-Tec inc ., "AEC 2001 "Finishing work shop (2001).

[6] Michael van Dijk , a Quality Control Analyst Almatis Rotterdam Laboratory (2011)

"Steel production, Cement production, non-ferrous metal production .

[7] C.F. Jones , et al., (1980), phil. Mag., A 42,267 .

[8] I.V. Azaroff, (1968), "Elements of X-Ray Crystallography", McGraw-Hill Book Company .

[9] TH.H.DE. Keijser, et al., (1982),J.Appl. Cryst., 15, 308.

[10] B.E. Warren (1969), "X-Ray Diffraction”, p.251-314 Addison-Welsiey.

[11] A.R. Stokes, (1948), proc. Phys. Soc., London, 61, 382.

[12] D. Louer, et al.,(1983), J. Appl. Cryst., 61,183.

[13] G.B. Mitra and N.K. Misra (1967), Acta Cryst., 22, 454

[14] C.G. Shull (1946), phys. Rev. 70,679.

[15] B.S. Acfarya and L.D. pradhan (1986), J. Appl. Cryst. 19,214 .

[16] S.A. Abass, Ph. D. Thesis University of Saddam (1997).

[17] S.M. Musa, M. Sc. Thesis University of Baghdad (1999).

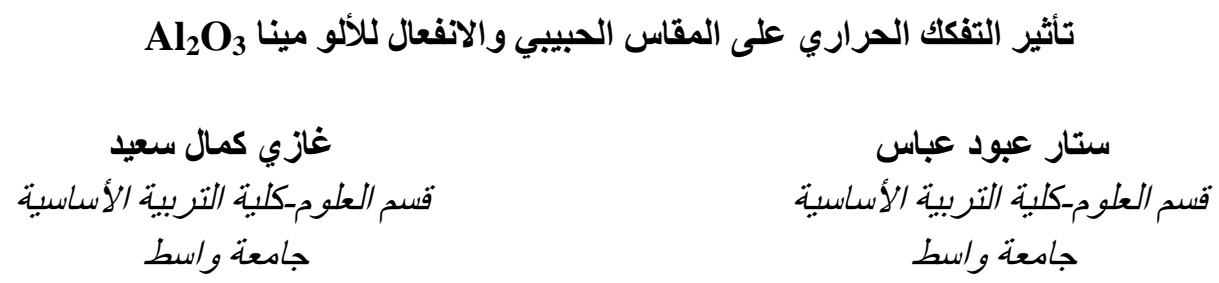




\section{University of Thi-Qar Journal Vol.10 No.1 Mar 2015}

Web Site: https://jutq.utq.edu.iq/index.php/main Email: journal@jutq.utq.edu.iq

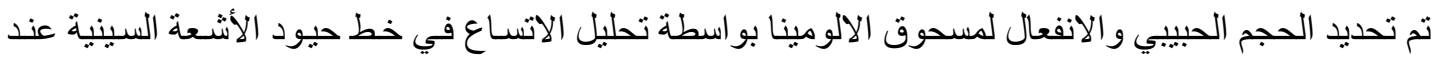

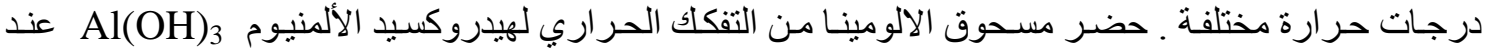

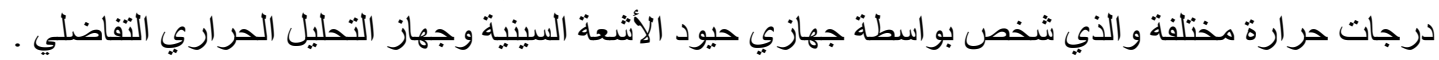

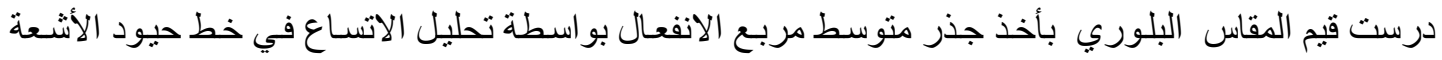

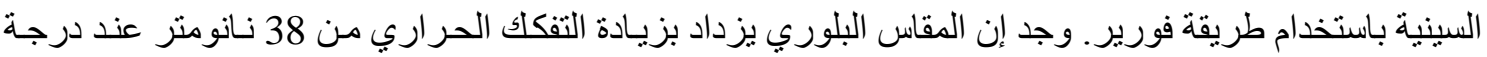

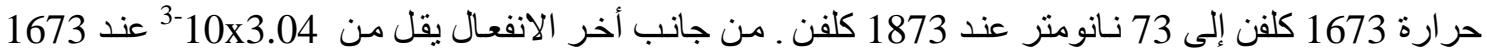

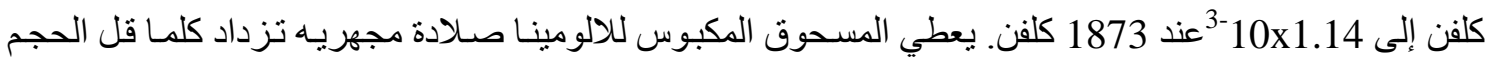
الحبيبي . 